\title{
The effects of integrating ICT resources into reading comprehension in Iranian high school
}

\author{
Jafari, Davood $\$ \\ University of Isfahan, Iran (Jafari.davood@yahoo.com) \\ Dabaghi, Azizolah \\ University of Isfahan, Iran (Dabaghi.fng@gmail.com) \\ Vahid Dastjerdi, Hossein \\ University of Isfahan, Iran (h_vahid@yahoo.com)
}

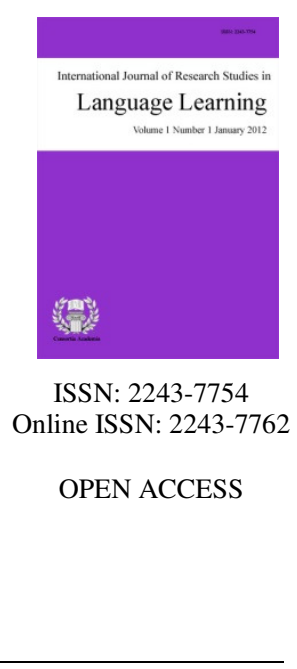

Received: 15 June 2014

Revised: 19 August 2014

Available Online: 24 September 2014

Revised: 19 August 2014
DOI: $10.5861 /$ ijrsll.2014.85

Accepted: 20 August 2014

\section{Abstract}

The purpose of the present study was to investigate the reasons and influential factors behind teachers' attitudes, use or non-use of information and communication technology (ICT) resources in vocabulary instruction in Iranian High School context. To have a better understanding of the effects of Integrating ICT resources into vocabulary instruction in Iranian High School Context with the use or non-use of (ICT) resources, the teachers' attitudes, perception and motivations were tested through various types of questionnaires and interviews as well as a comparison between the results obtained from immediate and delayed posttests of the students whose teachers integrated ICT resources with those whose teachers took the ordinary rout of teaching. The immediate and delayed posttests of sixty students whose teachers showed willingness to integrating ICT resources into vocabulary instruction were compared with those of sixty other students whose teachers took the traditional procedures of teaching vocabulary. Inferential and statistical description of their finals revealed that the former outperformed the latter. It was also revealed that females were more successful than their male counterparts, even with the same background knowledge. The findings further showed that after taking part in computer in-service training, almost all the teachers became interested in integrating ICT resources in their classes. The findings also illustrated the importance of teachers' vision of technology itself, their readiness to use ICT resources, their experience with it, the importance of in-service training, their level of computer skill and competence, the cultural environment surrounding them, and the introduction of ICT to schools and English institutes which could result in shaping their attitudes, perceptions and motivation toward computer technology.

Keywords: information and communication technology; attitudes; perception; motivation; in-service training 


\section{The effects of integrating ICT resources into reading comprehension in Iranian high school}

\section{Introduction}

The influence of technology on education in EFL/ESL settings and contexts has been inspected by numerous studies and a number of researchers (Baylor \& Ritchie, 2002; Arkin, 2003; Bordbar, 2010; Baradaran \& Davari, 2010; Marcinkewicz, 1994, Mokhtari, 2012; Talebinezhad \& Azizi Abarghoui, 2013). The most significant and common findings of those studies are related to the effectiveness of the use of technology in education and how it helps to develop teaching methods and students' knowledge (Aziz Mohammadi \& Samadi, 2014; Talebinezhad \& Azizi Abarghoui, 2013; Miner, 2004; Timucin, 2006). In schools teachers are seen to be active agents in the process of modifications and performance of new ideas as their beliefs and attitudes may support or hinder the success of any educational reform such as the utilization of an innovative technology program (Woodrow, 1991; Levin \& Wadmany, 2006a). Some researchers believe that language courses are faced with noticeable changes by utilizing modern technology (Xiong, 2008; Zhao \& Liu, 2011 as cited in Talebinezhad \& Azizi Abarghoui, 2013).

Technology-empowered education as Wernet, Olliges, and Delicatch (2000) believe is becoming an increasingly important part of higher and professional education. Technology not only gives learners the opportunity to control their own learning process, but also provides them with ready access to an infinite amount of information over which the teacher has no power or control (Lam \& Lawrence, 2002). Its innovations have gone hand-in-hand with the growth of English and are changing the ways in which we learn. Computer technology as Arkin (2003) believes is changing language learning partly because it gives rise to new vocabulary instruction and more importantly because the users of this device drive the language in certain directions.

Miner (2004); Al-Mekhlafi (2004); Levin and Wadmany (2006b) believe that a number of countries' policy makers have been convinced to integrate internet and information technology into their educational systems in order to produce workforces that are educated, skilled in new technologies and able to face global challenges. The extensive sources and chances that computers and Internet offer language learners have brought about new tools, methods and strategies in language instruction.

The aforementioned approaches are based on Constructivism in which learning is viewed as an ongoing state, constructed through individuals' cognition and social interaction. Considering technology revolution, we are now entering into a new era where computer technology is offering a large number of exciting new applications (Divaharan \& Wong, 2003).

Since Iranian EFL junior and senior high school students have severely suffer from limited opportunities for authentic language learning and almost no one have the opportunity of having face to face interaction which is necessary for language acquisition, this study is an attempt to examine the effects of Iranian high school teachers' attitudes, perceptions and motivation towards integrating ICT resources into reading comprehension. It also attempts to investigate the factors that influence teachers' perceptions as well as their use or non-use of computer technology and computer assisted language learning (CALL). It is finally designed to investigate to what extent facilities, chances, and trainings offered to Iranian teachers, assist them in their reading comprehension.

With respect to the development on computer technology and the fact that learning does not merely occur inside the class it is assumed that ICT application will meet the needs of the Iranian EFL classrooms. Due to the new conditions and reforms occurred in Iranian Ministry of Education, little research, however, has been conducted into the effects of application of computer technology in reading comprehension teaching and 
The effects of integrating ICT resources into reading comprehension in Iranian high school

learning. The outcome of such exploration is expected to provide a way of constructing an interactive learning environment within which the Iranian EFL teachers can associate with each other in the target language instruction.

The current Iranian teaching and learning setting have generated two ideas from which this research begins: 1) how to enhance the Iranian teachers' attitudes and perceptions concerning computer assisted language learning (CALL), and 2) how the Iranian teachers can encourage their students to cope with the new conditions of teaching and learning processes.

So the present study was an attempt to investigate Iranian EFL male and female teachers ' attitudes, perceptions and motivation on the integration of ICT resources into their language teaching. It definitely looked at how teachers identify and utilize computer technology in reading comprehension and vocabulary enhancement program and its possible classroom application. Also, this study looked at how Iranian high school teachers reflect on the application of computer technology resources, how they use high-tech facilities, how they absorb their students towards the ICT application in reading comprehension in a particular sense, and how they feel about on-line communication program. The present study is also designed to investigate the factors influencing teachers' attitudes, perceptions and motivation concerning computer technology resources.

\section{Background of the study}

As international communication increases in the trends towards globalization, the demands for communicative competence in English is increasing more and more in language classes and institutes. Teaching English in language institutes, however, fails to develop English proficiency for communication which appears to result from lack of interpersonal interaction in English as a foreign language (EFL). According to the studies done on making the teaching and learning processes more meaningful, lots of theoretical perspectives including Constructivist approach, Krashen's Compelling Hypothesis, Computer Mediated Approach, Interaction Hypothesis and sociocultural perspectives, deal with this matter. Learners are considered to be active organisms seeking meaning (Vygotsky, 1934, 1966). Learning is authentic and interdisciplinary and extends beyond the classroom (Brooks \& Brooks, 1993; Duffy, 1992).Constructivist learning in classrooms is collaborative in nature and happens in a learner-centered environment where students are, to a considerable degree, in control of their own learning (Davis \& Sumara, 2003). Learning is cooperative or independent where students are the decision makers and the teachers act as facilitators and directors.

Schools and other Language institutions have found out that the fast increase in the accessibility and availability of computers and other technology sources in twenty first century world's conditions emphasized the significance of pedagogical technology within schools and language institutes. Marcinkiewicz (1994) believes that there is a great deal of support for integrating technology and many school managers have started to spend significant amounts of money in technology resources to increase the quality of teaching and learning, and are looking at ways of effectively including these tools into their program, curriculums, and classrooms. The role and responsibility of teachers are becoming more fundamental as they are supposed to assimilate their teaching methods with ICT resources in their teaching. Development in integrating ICT resources has empowered teachers to have access to pedagogical and educational technology resources available through advances in computer assisted instruction (CAI) and language learning (CALL). However, not all teachers are willing to include computer technology into their instruction.

Although technical advances continue to become known with computer technology and resources, with CALL the focus is more on pedagogy, rather than technology (itself) (Boswood, 1997). The emphasis is on ways of utilizing resources rather than keeping up with and investing in the latest technology resources. Integrating computer technology can enhance the learners' ability and increase the learning opportunities. The amount and variety of types of language input accessible via the computer technology encourage learners to practice more with language, take risks and explore language and learning. Integrating ICT resources require different roles 
and skills both for tutors and pupils. Similarly, computer technology can be used in many different ways to support teaching, such as using the features of word- processing programs to help students develop their skills in writing and editing written work; using e-mail to engage students in collaborative learning activities with their friends and teachers within and outside their learning context; working with the Internet in searching, gathering and organizing information; language practice (e.g. grammar and vocabulary practice exercises, pronunciation work, games and so on) with multimedia CD ROMs, ( having online communication with their fellow partners); and using concordance programs to analyze genuine texts to discover and apply rules and patterns of language (Boswood, 1997).

Although there are lots of ICT resources to be applied in language learning and it is required to have the computer knowledge, but even with simple tools and limited knowledge of computers can still be incorporated into language learning curriculum. Although computer resources are available in many schools, and it is believed that they improve the quality of educational activities, not all teachers are willing to adopt them as much as expected by researchers, and school managers (Marcinkiewicz, 1996; Dusick, 1998).

Although teachers today identify the importance of merging technology with their instruction and course syllabi (Dupagne \& Krendl, 1992), successful implementation is often blocked by both external and internal barriers. Lack of access to computers and soft wares, insufficient time to plan, and inadequate technical and administrative support and training are related to external barriers and teachers' beliefs about teaching and computers, teachers' established classroom practices and unwillingness to change, lack of relevance of computer technology resources in teaching, and lack of self-confidence are related to internal barriers.

In order to ensure that teachers have the required ability to effectively apply ICT resources throughout the curriculum, schools need to develop programs to train teachers, i.e., encouraging them to apply ICT resources through pre and in-service training. Baylor and Ritchie (2002) predict that integrating technology into instruction successfully depends on two various variables: teacher readiness to change and the degree to which teachers experience and practice with technology. Regardless of the amount and complexity of technology resources, teachers will not apply them without having knowledge, skills, and attitudes necessary to incorporate them into language instruction. Baylor and Ritchie (2002) believe that through self- education and pre/ in-service training by the language institutes, integrating computer technology will be guaranteed.

\subsection{Research questions and hypotheses}

Considering the aforementioned goals, the following research questions have been considered as the fundamental factors to be dealt with throughout the study.

Q1: Is there any significant difference between Iranian EFL learners' performance in reading comprehension before and after the application of ICT resources?

Q2: Is there any significant difference between Iranian male and female EFL learners' performance in reading comprehension regarding before and after the application of ICT resources?

Considering the aforementioned research questions, this study dealt primarily with the teachers attitudes, perceptions and use or non- use of ICT resources in language teaching and learning that were likely to govern the whole research, then it aimed at investigating the possible influence of teachers' attitudes, perceptions and motivations on their students learning English. Thus, the following hypotheses about the application of ICT resources in language instruction in Iranian EFL setting formulated to help the author arrive at a concrete basis to address the above questions.

Ho1: There is no significant difference between Iranian EFL learners' performance in reading comprehension before and after the application of ICT resources.

Ho2: There is no significant difference between Iranian male and female EFL learners' performance in 
reading comprehension regarding before and after the application of ICT resources.

\section{Method}

\subsection{Participants}

Teachers - Since the present study was going to test the possible impacts of integrating resources in Iranian EFL setting, the teachers who were busy teaching in high schools were considered as the potential participants of this study. After an online call 40 teachers, both male and female, registered their names to take part in the experiment voluntarily. The participants' age ranged between 28 to 46 years old and they had 6 to 24 years of teaching experience. The participants were divided equally to four groups; experimental and control groups. The teachers in the experimental groups, male and female, were supposed to integrate ICT resources in their reading instruction while the control groups, male and female, went on ordinary approaches of teaching. To achieve the purposes of the present study an attitude questionnaire and some other data collection instruments were used to see if the results of integrating ICT resources in to language instruction. Questionnaires, among other data collection instruments, are easy and practical means of data gathering from a large population (O' Maley \& Chamot as cited in Arkin, 2003).

Students - Since the final goal of any educational activity and its possible influence should be visible or grasped in the domain of the students' behaviors, the students' performance were taken into consideration before and after the treatment. So a group of one hundred and twenty students whose teachers took part in the experiment were appointed to the parallel groups as their teachers, that is, thirty in each group.

\subsection{Materials}

For the purpose of this study, the following instruments were applied:

$>$ The bio-data questionnaire: this questionnaire was designed so as to get information about participants' background knowledge. In this questionnaire the researcher asks for some pieces of information considering the participants' age, teaching experience, the level at which they were teaching, whether they had passed certificate of computer and teacher training, whether they had been in an English speaking country, how much they knew about computer, whether they knew how to compose email and send it to a partner, and so on

$>\quad$ An attitude questionnaire was given to the experimental groups before and after the application of ICT resources to see if their reactions towards the integration of ICT resources would have any changes. The questionnaire contained twenty items of a close ended question adopted from Likert scale tested the level of the participants' familiarity with computer, and some related information.

$>\quad$ The homogenize the students' level of English mastery, a sample of previously validated sample of vocabulary and reading comprehension test based on the students' book (II) was prepared and administered to them and those whose scores were one point below or above the group's mean score were selected as the participants of the study.

$>\quad$ To see the probable effects of integrating ICT resources on the students' performance two samples of their books' content reading comprehension with thirty questions (i.e., 15 multiple choice questions and 15 reading comprehension one) were used after the experiment as the immediate and delayed posttests with fifteen days interval between the two.

\subsection{Procedure}

After the selection of the participants with similar previous background knowledge but different viewpoints 
and attitudes, i.e., those who had positive attitudes and perceptions towards integrating ICT resources into language instruction and being able to use compute regularly for the purposes of e-mail, on line communication, word processing programs, providing power points for the class contents and any other multimedia programs, and those who were in opposed with integrating ICT resources into language instruction, they were assigned into two experimental and two control groups, with ten males and females in each. The control groups followed the routine approach of teaching while the experimental groups were kindly invited to take part in computer workshops to review what they had previously learned about the application of computer technology, how to use computer programs, how to compose e-mails and to have on line communication, how to produce multimedia programs and hence teach reading comprehension through ICT resources application. Both the experimental and control groups taught their students reading comprehension through a period of twelve ninety minute sessions. Those who had positive attitudes towards integrating ICT resources into language were asked to provide the situation in a way that their students would be able to take part in the following procedures as out of the class activities:

D Jigsaw: the jigsaw tasks were essentially sequential ordering tasks, which presented each participant with a series of three pictures that needed to be mixed in the correct order to reveal a humorous story. The participants in experimental groups tried to take part in this activity as a kind of practice during the course using both offline and on line internet services.

D Decision-making: the decision making tasks necessitated participants to reduce their total number of items or objects held from ten to five. Each task included a total of ten target lexical items (five for each learner) with the text and corresponding color graphic images listed at the bottom of the task sheet.

D Choosing among the presented list of the words to see the most heard applied words which best match with the meaning of the definition given.

The next step in evaluating the aforementioned hypotheses was to consider the obtained data in a quantitative and qualitative approach. The data derived from the present study were analyzed by the software; SPSS, to see whether the presupposed hypotheses were approved or rejected.

\section{Results and Discussion}

The data gained through the administration of posttests as well as the questionnaire were closely analyzed. Some complicated relationships were found among teacher-oriented educational and cultural hints, teaching experience, computer learning, age, gender, participants' collaboration with each other, etc. The data obtained from the questionnaire revealed the following matters about the teachers:

1. There was a negative relationship between age and ICT resources application, i.e., the older the teachers were the less they tended to apply computer resources in their teaching curriculum.

2. The more the teachers were knowledgeable in computer programs the more they used them in their instruction, that is, in-service computer training guaranteed ICT resources application.

3. Highly experienced teachers preferred traditional approaches of teaching and showed fewer tendencies to use ICT resources.

4. The younger the teachers were, the more they tended to change and to take risks of trying new processes of language instruction.

5. The older the teachers were the more they resisted to any change although they admitted the importance and benefits of integrating ICT resources into language instruction.

6. Female EFL teachers showed more eagerness towards integrating ICT resources into language 
instruction than their male counterparts.

7. Some teachers declared that regardless of their usefulness, the in-service training courses proved to be less useful and applicable by most participants.

8. Most teachers admitted that there is a big gap or controversy between content of the course with final exams. Too much homework to be done by the students was another thing needed to be curious about.

9. In order to motivate the teachers to apply ICT resources, the participants suggested that if we were supposed to compile the course content, we would provide it in a way to be supportive and influential in terms of integrating ICT resources into language teaching and learning.

10. Some participants suggested that if it were possible to offer the final exam in an online way, it would be more practical to provoke a larger number of learners to accept the new learning curriculum.

11. Results showed that even with adequate access to hardware, software, technical support and computer professional learning, most male participants in the study made limited use of ICT resources in the classroom.

Table 1

Descriptive Statistics of Control and Experimental Groups

\begin{tabular}{|c|c|c|c|c|c|}
\hline Group & Gender & & Pre.reading & Post.reading & Follow.reading \\
\hline \multirow{9}{*}{ Experimental } & \multirow{3}{*}{ Male } & Mean & 17.59 & 20.20 & 19.59 \\
\hline & & $\mathrm{N}$ & 30 & 30 & 30 \\
\hline & & Std. Deviation & 2.92076 & 3.70010 & 3.16117 \\
\hline & \multirow{3}{*}{ Female } & Mean & 17.56 & 22.73 & 19.98 \\
\hline & & $\mathrm{N}$ & 30 & 30 & 30 \\
\hline & & Std. Deviation & 3.81799 & 3.33742 & 3.18469 \\
\hline & \multirow{3}{*}{ Total } & Mean & 17.58 & 21.47 & 19.78 \\
\hline & & $\mathrm{N}$ & 30 & 30 & 30 \\
\hline & & Std. Deviation & 3.38641 & 3.73815 & 3.17238 \\
\hline \multirow{9}{*}{ Control } & \multirow{3}{*}{ Male } & Mean & 17.58 & 17.95 & 17.30 \\
\hline & & $\mathrm{N}$ & 30 & 30 & 30 \\
\hline & & Std. Deviation & 3.51865 & 3.40254 & 3.63595 \\
\hline & \multirow{3}{*}{ Female } & Mean & 17.62 & 18.19 & 17.20 \\
\hline & & $\mathrm{N}$ & 30 & 30 & 30 \\
\hline & & Std. Deviation & 3.59548 & 3.56685 & 4.34364 \\
\hline & \multirow{3}{*}{ Total } & Mean & 17.60 & 18.07 & 17.25 \\
\hline & & $\mathrm{N}$ & 30 & 30 & 30 \\
\hline & & Std. Deviation & 3.54988 & 3.48033 & 3.99738 \\
\hline \multirow{9}{*}{ Total } & \multirow{3}{*}{ Male } & Mean & 17.58 & 19.08 & 18.45 \\
\hline & & $\mathrm{N}$ & 60 & 60 & 120 \\
\hline & & Std. Deviation & 3.22678 & 3.72184 & 3.58704 \\
\hline & \multirow{3}{*}{ Female } & Mean & 17.59 & 20.46 & 18.59 \\
\hline & & $\mathrm{N}$ & 60 & 60 & 120 \\
\hline & & Std. Deviation & 3.69562 & 4.13252 & 4.04688 \\
\hline & \multirow{3}{*}{ Total } & Mean & 17.59 & 19.77 & 18.52 \\
\hline & & $\mathrm{N}$ & 120 & 120 & 120 \\
\hline & & Std. Deviation & 3.46551 & 3.98899 & 3.82058 \\
\hline
\end{tabular}

Although all the participants emphasized the importance of investing on hi-tech in education, they insisted on changing the society's beliefs, customs and attitudes as well as some changes in cultural background of the society if a kind of reform is going to take place in language teaching and learning in Iran. Furthermore emphasized the importance of in-service training related to the application of ICT resources into language instruction. 
Jafari, D., Dabaghi, A., \& Vahid Dastjerdi, H.

To test the hypotheses, the raw data was given to SPSS software to process the information and the subsequent computation was made. SD, frequency and inferential statistics were used in the analysis of the data gathered in all stages of the present study, and qualitative and quantitative data processing were applied to evaluate the above research questions. The students' scores in immediate and delayed posttests were given to SPSS to process the subsequent computation; hence the following information based on each research question was obtained.

Table 1 shows the descriptive statistics of the participants' mean scores across on the control and experimental groups. It can be seen in the above table that the difference between mean scores for the results of control group considering pretest, immediate and delayed post-tests are $(17.62,18.06, \& 17.20)$ and those of the experimental groups regardless of their gender are $(17.58,21.48, \& 19.78)$ is significant. As it is evident from the above table the experimental groups outperformed the control ones even in delayed posttests. To have a better grasp, the following bar graph indicates the matter:

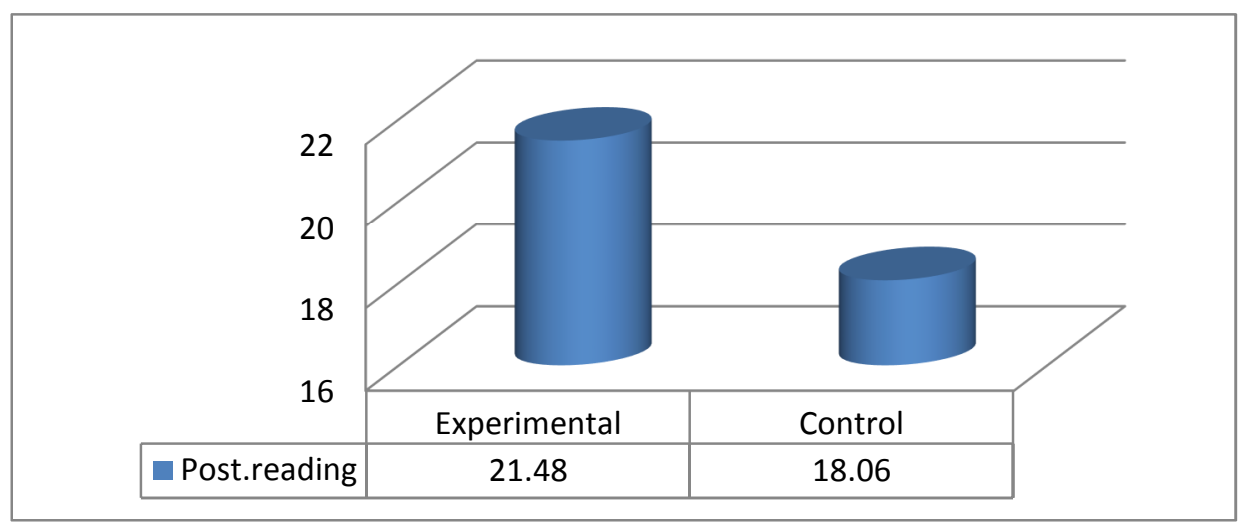

Figure 1. Comparison of the participants' mean scores in reading comprehension posttests

The above bar graph signifies that there is a significant difference between the experimental groups' performance with that of control groups' in their reading comprehension posttests. It shows that the experimental mean score in immediate posttests is 21.48 while that of the control groups is 18.06 .

\section{Results}

Q1: Is there any significant difference between Iranian EFL learners' performance in reading comprehension before and after the application of ICT resources?

In order to find answer to the above question, the total performance of the experimental group was compared with that of the control group. The following table shows. As it is evident from the following table, there is a meaningful difference between Iranian high school students' learning vocabulary regarding ICT resources application by their teachers. A careful look at the table, shows that at least one of the variables, i.e., the experimental mean scores is significantly meaningful compared with those of the control group.

Table 2

Multivariate Tests

\begin{tabular}{llllllll}
\hline & Value & $\mathrm{F}$ & $\begin{array}{l}\text { Hypothesis } \\
\mathrm{df}\end{array}$ & Error df & Sig. & $\begin{array}{l}\text { Partial Eta } \\
\text { Squared }\end{array}$ & $\begin{array}{l}\text { Observed } \\
\text { Power }^{\mathrm{b}}\end{array}$ \\
\hline $\begin{array}{l}\text { Pillai's trace } \\
\text { Wilks' lambda }\end{array}$ & .424 & $174.227^{\mathrm{a}}$ & 2.000 & 474.000 & .000 & .424 & 1.000 \\
$\begin{array}{l}\text { Hotelling's } \\
\text { trace }\end{array}$ & .735 & $174.227^{\mathrm{a}}$ & 2.000 & 474.000 & .000 & .424 & 1.000 \\
$\begin{array}{l}\text { Roy's largest } \\
\text { root }\end{array}$ & .735 & $174.227^{\mathrm{a}}$ & 2.000 & 474.000 & .000 & .424 & 1.000 \\
\hline
\end{tabular}


The above table shows that the difference between the experimental group's performance and that of the control group in reading comprehension posttests are significant $(p<.05)$. Various tests done by SPSS software approves the result. The difference can be seen through looking at the above bar graph. So the first research hypothesis is rejected.

Q2: Is there any significant difference between Iranian male and female EFL learners' performance in reading comprehension regarding before and after the application of ICT resources?

In order to test the above research question, all the participants took part in an immediate reading comprehension test which was designed based on their class content. Using SPSS software, the participants' results were processed. The following bar graph represents the outcome.

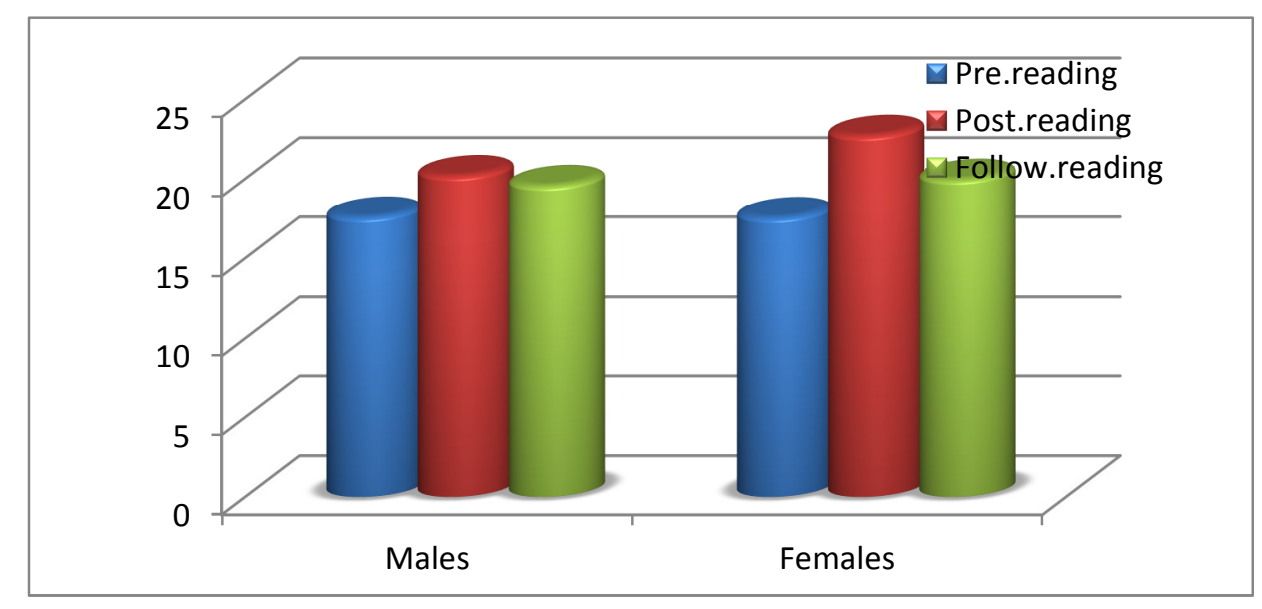

Figure 2. Comparison of male and female performance in pre/immediate and delayed posttest

The above bar graph shows Iranian male and female EFL learners' performance in pre/ immediate and delayed posttests whose teachers integrated ICT resources into language instruction. As it are evident females outperformed males in their immediate posttests (22.73 vs. 20.20). The y was superior to their male counterparts even in their delayed posttests (19.58 vs. 17.25) which had been held with a fifteen days interval. In other words there is a significant difference between Iranian male and female EFL learners' performance in their reading comprehension before and after the application of ICT resources, so the second hypothesis is rejected.

\section{Conclusion}

The present study attempted to shed more light on the possible effects of Iranian high school EFL teachers' attitudes, perceptions and motivation on integrating ICT resources into language instruction. It aimed to find the answer to two research questions: to see the possible differences between Iranian male female EFL learners' performance in reading comprehension before and after the application of ICT resources. The findings of the study substantiate the initial belief regarding the fact that learners in the experimental group were able to enhance their reading comprehension while their teachers integrated ICT resources. Considering research questions, the difference between participants' scores in immediate and delayed post-tests was significant and therefore integrating ICT resources into language instruction did have positive impact on the students' performance in reading comprehension as well as the significant difference between male and female learners.

The present study is part of a vast amount of literature that provides evidence for the benefits of integrating ICT resources into language instruction. The majority of empirical studies conclude that positive attitudes and perceptions towards integrating ICT resources have encouraging effects on the language learners, regarding the way these resources create a fruitful learning atmosphere and eliminate possible negative affective factors such as lack of self-confidence, of motivation, the existence of anxiety and stressful environment. 
Considering the application of this study, since Iran's Ministry of Educational has moved towards equipping schools with hi-tech appliances during the last decade and lots of school managers have invested a large amount of money on providing their schools with such facilities, it can be claimed that the most important contribution of this study will be its applicability to Iranian EFL setting, i.e. if high school learners are in contexts where the environment is creative and enjoyable, their motivation for learning English would be increased and their anxiety and stress would be decreased. The findings of the present study can be useful for policy makers as well. If they pay due attention to equipping schools with ICT resources, they can make their books compatible with learners' needs to create more relaxing processes of language learning for them.

As it has been mentioned before, the present study aimed at investigating whether ICT resources application had any significant impact on Iranian high school students English on the one hand and to see whether there is any meaningful difference male and female performance. Since all the participants had nearly the same previous background information and their difference originated due to the way their teachers taught them, that is, the control group via ordinary processes of reading comprehension while the experimental group went through a series of various activities including jigsaw models, decision making and choosing among the presented words, the significant difference between them could be logically attributed to the influence of utilizing ICT resources inside and outside the class activities and through on-line communication among their teachers and their friends.

Furthermore, the researcher wanted to see the possible difference between male and female students in this regard, so their immediate and delayed post-tests were taken into consideration and the results showed that females outperformed their male counterparts in their finals. When the students whose teachers integrated ICT resources into reading comprehension were asked to mention if the feel any difference between learning through ordinary processes of language learning and learning via utilizing hi-tech ,they asserted that using ICT resources caused them to involve freely expressing themselves without any stress and fear of making a fool of themselves, creating a more friendly atmosphere, providing them greater opportunities to practice in a quite different way and being able to monitor their practice.

Considering the importance and presence of high tech appliances in education, developing countries such as Iran, the educational policy makers have the responsibility not merely to provide computers for schools, but also to raise a culture of acceptance amongst the end-users of these tools. Finally, although CCTT training and knowledge may be a crucial factor to enhance ICT integration into language instruction, it may not be enough. If educational policy makers as well as school managers pay considerable attention to course content, investing on high tech facilities such as smart boards, promoting computer systems, widening band-width for online curriculum accompanied with providing the teachers with in service training, the present difficulties in language instruction would be eliminated.

A final word is that since Iranian EFL teachers are the most important elements of teaching curriculum, they can make use of the outcomes of this study to provoke their students' motivation and interest. However, this study has a number of limitations which should be acknowledged. The first limitation is that the present study may not be thoroughly generalizable, that is, since not all parts of the country have been provided with ICT resources for the students, so the findings of the study must be interpreted with great cautions. Second, since the present study dealt with a small sample of a huge population, the findings of the study reveal the attitudes, perceptions and motivation of these teachers so the findings may not be suitable to generalize to all Iranian EFL teachers all over the country who may face various conditions different from those of the participants of this study. Another limitation of the study is that the researcher did not have the chance to have class observation to test whether the teachers integrate computer technology and also to see whether they use online communication as often they claimed while replying to questions posed in questionnaire, and if they apply them truly or not. The last issue is the question of confidentiality. To be able to select adequate numbers of participants, participants were asked to fill their names in the section of the questionnaire. Although they were informed that the data they provided, asking them to write their name might have affected some teachers' responses. 


\section{References}

Al-Mekhlaphi, A.( 2004).The effect of interactivemultimedia on learning English as a second language. Proceedings of the fifth Annual UAE university Research Conference (Vol.2, pp. 123-126). Al-Ain, UAE.

Arkin, A. I. (2003). Teachers' attitudes towards computer technology use in vocabulary instruction. Unpublished Masteral thesis, University of Bilkent, Istanbul.

Aziz Mohammadi, F., \& Samadi, F. (2014). The impact of call on improving Iran students' accent. Indian Journal of Scientific Research, 7(1), 794- 798.

Baradaran, A., \& Davvari, Z. (2010). The impact of utilizing computer assisted language learning on EFL learners' foreign accent reduction. Journal of English Language Studies, 1(4), 41-62.

Baylor, A. L., \& Ritchie, D. (2002). What factors facilitate teacher skill teacher morale, and perceived student learning in technology. Computers \& Education, 39(4), 395- 414. http://dx.doi.org/10.1016/S0360-1315(02)00075-1

Bordbar, F. (2010).English teachers' attitudes towards computer- assisted language learning. International Journal of Language Studies, 4(3), 179-206.

Boswood, T. (1997). New ways of using computers in language teaching. Alexandria, VA: TESOL.

Brooks, J. G., \& Brooks, M. G. (1993). In search of understanding: The case for constructivist classroom. Alexandria, VA: ASCD.

Davies, S. (2003). Content based instruction in EFL contexts. Internet TESL Journal, IX(2). Retrieved from http://iteslj.org/Articles/Davies-CBI.html

Davis, B., \& Summara, D. (2003). Why aren't they getting this? Working through the regressive myths of constructivist pedagogy. Teaching Education, 14(2), 123-140. http://dx.doi.org/10.1080/1047621032000092922

Divaharan, S., \& Wong, P. (2003). Student-centered learning: Microlessons. In S. C. Tan \& F. L. A. Wong (Eds.), Teaching and learning with technology, An Asia-pacific perspective (pp. 1-6). Singapore: Pearson Prentice Hall.

Duffy, T. M., \& Krendell, K. A. (1992). Constructivism: New implications for instructional technology. Hillsdale, NJ: Lawrence Erlbaum Associates.

Dupagne, M., \& Krendell, K. A. (1992). Teachers' attitudes toward computers: A review of the literature. Journal of Research on Computing in Education, 24(3), 420-429.

Dusick, D. M. (1998). What social cognitive factors influence faculty members' use of computers for teaching? A literature review. Journal of Research on Computing in Education, 31(2), 123-137.

Krashen, S. (1981). Second language acquisition and second language learning. Oxford. Pergamon.

Krashen, S. (1985). The input hypothesis. New York: Longman.

Krashen, S. (1987). Applications of psycholinguistic research to the classroom. In M. Long \& J. Richards. (Eds.), Methodology in TESOL (pp. 33-44). New York: Newbury House.

Lam, Y. (2000). Technophiliacs, technophobia: A preliminary look at why second-language teachers do or do not use technology in their classrooms. Canadian Modem Language Review, 56(3), 389-420. http://dx.doi.org/10.3138/cmlr.56.3.389

Lam, Y., \& Lawerence, G. (2002). Teacher-student role redefinition during a computer-based second language project. Computer Assisted Language Learning, 15(3), 295-315. http://dx.doi.org/10.1076/call.15.3.295.8185

Levin, T., \& Wadmany, R. (2006a). Teachers' beliefs and practices in technology-based classrooms: A developmental view. Journal of Research on Technology in Education, 39(2), 157-181. http://dx.doi.org/10.1080/15391523.2006.10782478

Levin, T., \& Wadmany, R. (2006b). Listening to students ${ }^{\text {ee }}$ voices on learning with information technologies in a rich technology-based classroom. Journal of Educational Computing Research, 34(3), 281-317. http://dx.doi.org/10.2190/CT6Q-0WDG-CDDP-U6TJ

Marcinkiewicz, H. R. (1994). Computers and teachers: Factors affecting computer use in the classroom. Journal of Research on Computing in Education, 26(2), 220-237. 
Jafari, D., Dabaghi, A., \& Vahid Dastjerdi, H.

Marcinkiewicz, H. R. (1996). Using subjective norms to predict teachers'computer us.Journal of Computing in Teacher Education, 13(1), 27-33.

Miner, T. (2004). Using technology to enhance learning: Instructor-or student-moderated discussion boards:

Which are more effective? Retrieved from http://www.cccone.org/scholars/04o5/TomMiner_final_report.pdf

Mokhtari, H. (2013). Iranian EFL learners' attitude towards CALL. Procedia Social and Behavioral Sciences, 70, 1630-1635. http://dx.doi.org/10.1016/j.sbspro.2013.01.232

O’Maley, J. M., \& Chamot, A.U. (1990). Learning strategies in second language acquisition. Cambridge: Cambridge University Press. http://dx.doi.org/10.1017/CBO9781139524490

Talebinezhad, M. R., \& Azizi Abarghoui, M. (2013). The Iranian high school students' attitude toward CALL and the use of CALL for EFL receptive skills. Theory and Practice in Language Studies, 3(2), 239-337. http://dx.doi.org/10.4304/tpls.3.2.329-337

Timucin, M. (2006). Implementing CALL in the EFL context. ELT Journal, 60(3), 262-271. http://dx.doi.org/10.1093/elt/ccl006

Vygotsky, L. S. (1934). Thought and language. Cambridge: MA: M.I.T. Press.

Vygotsky, L. S. (1996). Development of higher mental functions. In A. N. Leontyev, A. R. Luria \& A. Smirnov (Eds.), Psychological Research in the USSR (pp. 11-46). Moscow: Progress Publishers.

Wernet, S., Olliges, R., \& Delicath, T. (2000). Post course evaluation of WebCT (Web Course Tools) classes by social work students. Research on Social Work Practice, 10(4), 487-504.

Wong, L. (2004). Using technology in a low-advanced ESL class. Retrieved from http://www.cccone.org/scholars/04-05/LettyWong_final_report.pdf

Woodrow, J. (1991). Teachers' perceptions of computer needs. Journal of Research on Computing in Education, 23(4), 475-496.

Xiong, X. (2008). An investigation of the use of CALL by college English teachers: Perspectives in a Chinese normal university. Queensland: University of technology. 